\title{
A Critical Review of the Word Classification System
}

\author{
Una revisión crítica del sistema de clasificación de palabras
}

\section{Razieh Gholaminejad ${ }^{1}$}

\begin{abstract}
In this reflective paper, we review the currently-used word classification system proposed by linguist Paul Nation $(2013,2015)$ and the position of the academic vocabulary in this system. Different lexical layers in this system are explained as well as the underlying assumptions. Then, taking a critical position, we raise a number of criticisms against three different aspects of Nation's classification. The first criticism involves the fact that the system has sacrificed function for form in developing the lexical layers. The second focuses on the problem of equating 'academic words' with Coxhead's (2000) Academic Word List (AWL) and 'high-frequency words' with West's (1953) General Service List (GSL). Finally, the system is criticized for the lack of an independent lexical layer for discipline-specific academic vocabulary by ignoring disciplinary variation at the level of academic words. The critical points raised in the paper can be useful for English for Academic Purposes (EAP) materials developers, teachers, test developers, and syllabus/curriculum designers.

Keywords: academic vocabulary, English for academic purposes / EAP, high-frequency words, technical words, word classification system

\section{Resumen}

En este artículo reflexivo, revisamos el sistema de clasificación de palabras utilizado actualmente propuesto por el lingüista Paul Nation $(2013,2015)$ y la posición del vocabulario académico en este sistema. Se explican las diferentes capas léxicas en este sistema, así como los supuestos subyacentes. Luego, adoptando una posición crítica, planteamos una serie de críticas contra tres aspectos diferentes de la clasificación que hace Nation. La primera crítica implica el hecho de que el sistema ha sacrificado la fun-

Razieh Gholaminejad received her PhD from Shahid Beheshti University and her BA and MA from University of Isfahan. Among her research interests are corpus linguistics, English for specific purposes, and discourse analysis. In addition to publications in national journals, she has published in Routledge and John Benjamins Publishing Company.

r_gholaminejad@sbu.ac.ir

Received: April 14th, 2020. Accepted: August 10 ${ }^{\text {th }}, 2020$.

This article is licensed under a Creative Commons Attribution-Non-Commercial-No-Derivatives 4.0 International License. License Deed can be consulted at https://creativecommons.org/licenses/by-ncnd/4.0.
\end{abstract}


ción por la forma en el desarrollo de las capas léxicas. El segundo se centra en el problema de equiparar las "palabras académicas" con la Lista de Palabras Académicas de Coxhead (2000) y las "palabras de alta frecuencia" con la Lista de Servicios Generales de West (1953). Finalmente, el sistema es criticado por la falta de una capa léxica independiente para el vocabulario académico específico de la disciplina al ignorar la variación disciplinaria a nivel de las palabras académicas. Los puntos críticos planteados en el documento pueden ser útiles para los desarrolladores de material, profesores, desarrolladores de pruebas y diseñadores de planes de estudios / planes de estudio de inglés para fines académicos.

Palabras clave: vocabulario académico, inglés con fines académicos, palabras de alta frecuencia, palabras técnicas, sistema de clasificación de palabras

\section{Introduction}

\section{Paul Nation's Word Classification System}

In order to determine a methodical sequence for teaching English words in ESL (English as a Second Language) or EFL (English as a Foreign Language) settings, researchers have always been interested in disambiguating vocabulary types by proposing different classification systems. Nation (1990, 2001) and Schmitt (2000) divided words into four categories: high-frequency, academic, technical, and low-frequency words. Later, Schmitt and Schmitt (2012) proposed a frequency-based classification of high, mid, and low-frequency words. These three levels included respectively the top 3,000, 4,000-9,000, and beyond the 9,000 -word families in terms of frequency bands. Inspired by the classification proposed by Schmitt and Schmitt (2012), Nation (2013, 2015) restructured his system. In the revised version of the classification system, Nation classified the levels based on both frequency (high, mid, and low) and text type (academic and technical). These levels are assumed to sequentially complement each other by serving the needs of different language users at any stage. The definitions provided by Nation for each level have been used by researchers as a basis for lexical studies, and in a sense, have developed into distinct constructs. In Table 1, an outline of the lexical layers proposed by Nation's classification is displayed. What follows is a description of each lexical level in his system separately.

Table 1. The Lexical Levels in the English Corpus

\begin{tabular}{|c|c|c|c|c|}
\hline High-frequency words & \multirow{3}{*}{ 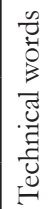 } & $\begin{array}{c}\text { General words } \\
\text { (GSL) }\end{array}$ & $\begin{array}{l}\text { The top } 1000,2000 \text {, } \\
\text { and } 3000 \text { words }\end{array}$ & \\
\hline Mid-frequency words & & $\begin{array}{c}\text { Academic } \\
\text { words (AWL) }\end{array}$ & $\begin{array}{c}\text { The } 4000,5000,6000,7000 \text {, } \\
8000 \text {, and } 9000 \text { words }\end{array}$ & \multirow{2}{*}{ 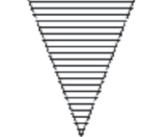 } \\
\hline Low-frequency words & & Rare words & The 10000 words onward & \\
\hline
\end{tabular}




\section{High-Frequency Words}

High-frequency words are defined as core words encountered "with the highest frequency and widest range" in "all kinds of use of the language" whether formal, informal, written or spoken (Nation, 2015, p. 571). They are the top 2,000-3,000 words of English, which cover approximately $80 \%$ of the tokens in texts. Many of them are function words and very common content words. The classic and most widely used high-frequency wordlist, which is still influential, is the GSL (General Service List) developed by West (1953). Derived from a five-million-word corpus, the GSL includes 2000-word families for which West used various selection criteria including frequency, learning ease, coverage, necessity, and stylistic level. The GSL provides coverage for $92 \%$ to $76 \%$ of fiction (e.g. Hirsh \& Nation, 1992), and academic texts (Coxhead, 2000), respectively.

\section{Mid-Frequency Words}

The words from the fourth 1,000 to the ninth 1,000 are classified as mid-frequency words. Nation (2015) considers academic words as the mid-frequency lexical layer, and asserts that knowledge of these two initial levels (i.e. high- and mid-frequency words) provides around 98\% coverage for most types of texts, a coverage which is supposed to allow unassisted comprehension of texts. Nation (2015) introduces Coxhead's (2000) Academic Word List (AWL) for this vocabulary level. Academic words serve as the next goal for learners who need to study at university via the medium of English. In addition to improving the serious tone of the writing (Nation, 2015), this lexical layer involves formal words that provide the building blocks for reporting the experiences of science (Coxhead \& Nation, 2001) through performing the rhetorical functions of exemplification, comparison and contrast, cause and effect, concession, and reformulation (Paquot, 2010, as cited in Gholaminejad, 2020a). In order to develop the AWL, Coxhead (2000) used a 3.5-million-word corpus of academic English texts in 28 sub-disciplines of four fields of Art, Commerce, Law, and Science, and developed 570 word families based on three criteria: (a) minimum frequency of occurrence (100 times in the corpus), (b) minimum range of occurrence (10 times in each of the 4 disciplines and in 15 or more subject areas), and (c) specialized occurrence (not included in the GSL words). The AWL, as demonstrated by Coxhead (2000), has a high coverage in academic texts (around 10\%), which together with the 2,000-word family of the GSL (which already provided $75-80 \%$ coverage) is supposed to allow for the unassisted comprehension of texts. The AWL is argued to serve as an essential measure of learners' academic competence. In fact, academic vocabulary can differentiate the academically wellprepared from the under-prepared college students (Kuehn, 1996). According to Nation (2001), knowledge of academic vocabulary doubles the amount of comprehensible texts 
for English for Academic Purposes (EAP) ${ }^{2}$ learners. This knowledge is essential not only for developing academic reading comprehension but also for enjoying an effective and appropriate writing skill (Corson, 1997). That is why it is argued that "any time spent learning it is time well spent" (Nation, 2001, p. 258).

\section{Technical Words: High, Mid, or Low-Frequency Words}

Technical vocabulary refers to domain-specific words, whose meaning is related to one specific area and may (or may not) require specialist knowledge to be understood (Chung \& Nation, 2004). In addition, they include acronyms, abbreviations, chemical formulas, and symbols (Nation, 2001). They are usually referred to as "terms" (Cabré, 1999, p. 81), as opposed to 'words'. They can be high, mid, or low-frequency words and are learnt while learners study within a particular subject area (Nation, 2015). That is why some practitioners argue that teaching this vocabulary level should not be assigned to English language teachers (Nation, 2001), but to those who are expert in the subject area.

In the beginning of the new millennium, it was assumed that technical vocabulary accounts for a very small percentage (about $5 \%$ ) of the words in academic texts (Nation, 2001; Coxhead \& Nation, 2001). However, later studies (Chung \& Nation, 2003, 2004) demonstrated that technical words account for up to one third of the text, covering $20-30 \%$ of tokens (Chung \& Nation, 2003), which can be increased if multi-word phrases are also included (Nation, 2015).

\section{Low-Frequency Words}

Low-frequency words comprise rarely-used terms, occurring from the 10th 1,000 onwards. They account for approximately $5 \%$ of the tokens in an academic text and include proper names, words rarely encountered in language use, infrequent words, and technical words of other academic disciplines (Nation, 2001).

Nation's classification system has served as a source for ELT materials developers and syllabus makers in arranging the order of presenting new vocabulary, selecting the lexical counting unit, or developing English wordlists. In view of that, ELT teachers have long used the GSL for teaching general vocabulary and EAP teachers in Higher Education have long

EAP is nowadays an increasingly developing area in ELT. Placed at the intersection of applied linguistics and education, EAP is usually defined as teaching English intended to help learners study or carry out research in English (Hyland \& Tse, 2007). Indeed, EAP is concerned with researching and teaching the English language which is used by those who intend to carry out academic tasks using English (Charles, 2013). Assuming that teaching the whole of a language is an impractical goal, EAP is "founded on the premise that the students' target language situations contain classifiable components which should be incorporated into English for Academic Purposes (EAP) courses in order to satisfy the specific language needs of learners" (Gholaminejad, 2020b, p. 105). 
used the AWL for teaching the academic vocabulary for students of different disciplines. Test developers have also adopted these wordlists in developing ELT and EAP tests. Syllabus makers and curriculum designers have also been inspired by this system. This classification system is even considered by many researchers, including Quero and Coxhead (2018, p. 53), as "the most comprehensive classification of its kind up to the present". In the present paper, however, some reflections on the problematic aspects of this classification system are proposed.

\section{The Underlying Assumptions of the System}

According to Nation (2015), frequency-based wordlists are an important resource for ELT, due to the fact that words in a language occur with different frequencies. Wordlists can be considered as the basis for designing ELT materials, or for developing vocabulary tests, for conducting research, and for ELT curriculum design. The purpose for developing a wordlist determines the way it is developed, which has a direct influence over the kind of corpus adopted by the researcher and the selected unit of counting (Nation, 2015).

The vocabulary levels included in Nation's (2015) classification are connected by assuming the GSL as a high-frequency wordlist, and the AWL as the mid-frequency wordlist. Nation maintains that the division between these levels is not clear-cut. Each level is a priority and complements the next one. High-frequency words are supposed to be essential for all language users (Coxhead \& Nation, 2001) and need to be acquired before others, while academic and technical words serve the language users with academic and specific purposes in mind.

\section{A Critical Discussion of the System}

In the present paper, a number of criticisms are leveled against Nation's (2015) word classification system.

\section{Sacrificing Function for Form}

The main issue about the system proposed by Nation (2015) is that it is primarily based on a superficial basis: frequency. This, indeed, sacrifices function for form. The top 3,000 words are classified as high-frequency, the 4,000-9,000 as mid-frequency, and beyond the 9,000 as low-frequency words. This arbitrary-based classification system disregards the fact that most words have multiple senses, which are determined by the context. Therefore, classifying words based on frequency cannot specify which of the senses of the word is more frequent. If a word such as 'head' is classified as high-frequency, it is not clear in what sense. More importantly, the same word which is classified in the high-frequency level can 
occur quite frequently in the mid-frequency (academic) or even technical vocabulary level with a different meaning. Researchers have illuminated this in their findings. Martínez, Beck, and Panza (2009), for instance, demonstrated that there are words from the GSL that appear frequently with academic meaning and use in their academic corpus. Also, Sutarsyah, Nation, and Kennedy (1994) found that some high-frequency words and academic words are used frequently in specialized texts, playing the role of technical vocabulary.

Hyland and Tse (2007) examined the meaning of the AWL items in their corpus and found that they did not occur with the same intended meaning across disciplines. They demonstrated that words behave semantically differently in various disciplines. Words in each discipline take on highly specialized meanings that are meaningful to members of the specific disciplinary communities. They illustrated the polysemy problem of words in the AWL items through words such as 'volume' which has various preferred meanings across science and in social sciences. Using lemmas as the counting unit has been an attempt to partially tackle semantic problems. However, it is not sufficient as the polysemy problem persists.

\section{Equating 'Academic Words' with the AWL and 'High-Frequency Words' with the GSL}

Another problem with the system is that the GSL (produced by West in 1953) is introduced as the high-frequency word level. Despite its wide use, the GSL has been criticized for its age, unit of analysis, and coverage. The new-GSL, developed by Brezina and Gablasova (2015), is a newer high-frequency wordlist which can be considered as a recent update of West's GSL. Four corpora characterizing different time periods were used for development of the newGSL. In addition to the criteria of frequency, dispersion, and distribution, lemmas were the unit of analysis. It contains 2,494 lemmas covering $80-81 \%$ of the texts. It is recommended that future word classification systems use updated and lemmatized high-frequency wordlists such as the new-GSL.

Additionally, Nation (2015) introduces the second level of his system by equating the 'academic words' with Coxhead's AWL indisputably. He recommends that the AWL be mastered by students subsequent to the first level. He seems to be closing his eyes to the rising criticisms against the AWL. Many researchers have demonstrated the limited use of the AWL for different disciplines. Chen and Ge (2007) found that only about half of the AWL's items were frequent in medical texts, and accordingly, concluded that a separate medical academic wordlist needed to be developed. Similarly, Li and Qian (2010) examined the presence of the AWL items in a financial corpus and found only a $28 \%$ overlap. Wang, Liang, and Ge (2008) found a 54.90\% overlap between the AWL and their medical corpus, and attributed the marked difference of the coverage of the AWL in different corpora to the argument that different disciplinary communities require discipline-based lexical repertoires. Martínez, 
Beck, and Panza (2009) demonstrated that the AWL not only contains words that learners may not need, but it is also deficient in words that they may need. Finding that only 92 out of 570 words on the AWL occurred frequently in their corpus, Martínez et al. (2009) suggested that a more restricted wordlist is required to be developed. Similarly, by identifying 128 nonAWL word forms that were used quite frequently in their corpus, Vongpumivitch, Huang, and Chang (2009) showed the prospective strength of building a field-specific academic list.

\section{Lacking an Independent Lexical Layer for Discipline- Specific Academic Vocabulary}

In his explanation about the technical lexical layer, Nation (2015) introduces the notion of disciplinary variation explicitly. To do so, he discusses the differences among the technical terms of different disciplines. He asserts that medicine, botany, and zoology have very large technical vocabularies, while applied linguistics, geography, and psychology have smaller technical vocabularies. However, the existence of such disciplinary variation seems to be ignored when it comes to the academic word level. Nation's classification system assumes that after learners have mastered high-frequency words, they should move to learn mid-frequency vocabulary, which is equalized to the AWL (Nation, 2015). In this system, regardless of their disciplines and how well the AWL can serve their needs, all learners are supposed to master the AWL to move on to the next phase.

However, a cursory glance at the contributions to the EAP literature in the past decades reveals that researchers have started to develop academic wordlists for each discipline independently. As research repudiates the equal usefulness of the AWL in serving the needs of students of all disciplines, an increasing trend toward the development of disciplinespecific academic wordlists has begun (Lei \& Liu, 2016).

So far, academic wordlists for computer science (Lam, 2001), engineering (Ward, 2009; Mudraya, 2006; Hsu, 2014), business (Hsu, 2011), medicine (Wang, et al., 2008; Lei \& Liu, 2016), agriculture (Martínez et al., 2009), environmental science (Liu \& Han, 2015), nursing (Yang, 2015), chemistry (Valipouri \& Nassaji, 2013), applied linguistics (Vongpumivitch et al., 2009) and language teaching and applied linguistics (Gholaminejad \& Anani Sarab, 2020) have been developed. Besides, a series of discipline-specific wordlists have been generated for secondary school education, covering eight core subjects: biology, chemistry, economics, English, geology, history, mathematics, and physics (Green \& Lambert, 2018). Researchers working in this area, by using corpus-based evidence, assert unanimously that a single academic wordlist cannot be used equally well for all disciplines. Furthermore, an Academic Spoken Word List (Dang, Coxhead, \& Webb, 2017) has been specifically developed for comprehension of academic speech in English-medium universities, based on 
the assumption that the linguistic features of academic spoken English are different from those of academic written English.

According to Gholaminejad and Anani Sarab (2020), the emergence of discipline-specific academic wordlists has shaped a new type of lexical layer at the intersection of academic words and technical terms, which can be added to Nation's classification system. Due to the lack of a clear definition for the notion of 'discipline-specific academic vocabulary' in Nation's classification system, researchers (e.g. Wang, et al., 2008; Vongpumivitch et al., 2009; Martínez et al., 2009; Valipouri \& Nassaji, 2013; Yang, 2015; Lei \& Liu, 2016) have adopted the common definition of 'academic vocabulary' as the words commonly used in academic texts across different disciplines and changed it into the words commonly used in academic texts across different subject areas within a discipline.

Thus, a novel construct has come into being without having a place in Nation's classification system. This has muddled up researchers, which is manifested in the unharmonious ways researchers in this area present their findings. For instance, while Ward (2009) repeatedly emphasized the "non-technicality" (p. 177) of their academic engineering wordlist throughout the paper, Wang, et al. (2008), developing a Medical Academic Word List (MAWL), included in their wordlist words such as lesion and vein that are typically classified as technical words. But they claimed that to people in medical field such words are academic. They explained that "Academic vocabulary is a class of words between technical and non-technical words and usually with technical as well as non-technical implications. The word families included in their wordlist (i.e. MAWL) are medical academic vocabulary common across various sub-disciplines of medicine but not within one single sub-discipline of medicine" (p. 451). On the other hand, Lei and Liu (2016) established a medical academic wordlist, which includes highly-technical terms such as cytokine, endothelial and tomography, as well as words typically classified as high-frequency such as age, best and group. Such disagreements in researchers' conceptualization of the academic vocabulary may be ameliorated by a clear operationalization of the construct of discipline-specific academic vocabulary in the future word classification systems.

\section{Conclusion}

A number of issues regarding Nation's word classification system have been discussed in the present reflective paper. Considering the criticisms, we propose that the next logical stage in improving future word classification systems should consider the following suggestions. First, the word levels should be classified not only based on frequency, but also based on the sense in which the words have been frequently used. It is recommended that senseidentifying software programs, such as WordStat dictionary builder (Provalis, 2016), be developed and used for this purpose. For instance, if a word such as 'head' is classified in the 
high-frequency category, it should be clear as to which sense and part of speech it occurred in the high-frequency lexical layer. Second, it is suggested future classification systems be founded on more updated and improved wordlists for the high- and mid-frequency level. Third, the construct of discipline-specific academic words needs to be added to the system as a separate level with a clear definition and operationalization.

Discipline-specific academic wordlists are important in that they focus learners' attention on the words that they most probably encounter in their own academic studies (Nation, 2013). This can create a shortcut to decrease the learning load, and also can increase learners' motivation by seeing the usefulness of the words that they have to learn and feel are relevant to their discipline. Underscoring the unique features in the academic words within disciplines, discipline-specific academic wordlists present a useful guide for EAP learners to closely meet their needs. Besides, if by vocabulary teaching we aim to help students with their academic education, then we should target students' immediate needs, rather than burdening them with irrelevant words they may rarely need. Students need to learn primarily those academic words which they most probably encounter in their own academic studies.

The points raised in the present paper can be useful for EAP materials developers, teachers, test developers, syllabus makers, and curriculum designers. Materials developers and syllabus makers, particularly in the development of graded readers, are recommended not to arrange the order of presenting new vocabulary merely based on the frequencybased word classification system proposed by Nation (2015). Rather, the selection and presentation of new words need to be principally a meaning-based process. That is, the most frequent sense in which words frequently occur should be the criteria for presenting the new words for each level. Furthermore, materials developers can consider adopting newer lemma-based academic wordlists and general core wordlists rather than the AWL and the GSL for developing the materials for the students of each level. ${ }^{3}$ Finally, the materials developers working in discipline-specific areas in higher education are recommended not to use discipline-crossing academic wordlists; rather, they need to develop their materials based on the academic wordlists developed separately for each individual discipline. As previously mentioned, discipline-crossing academic wordlists, such as the AWL, are derived from the corpus of a variety of different disciplines. This overlooks the fact that each word can occur with a different sense in each discipline (Hyland \& Tse, 2007).

In addition, language teachers and test developers are recommended to present and evaluate the English language words based on the most frequent meaning of the word. It

For instance, Gardner and Davies (2014) developed the Academic Vocabulary List (AVL) using lemmas as the counting unit. They argued that lemmas (inflectional relationships only) should be preferred to word families (inflectional and derivational relationships) in developing wordlists. In addition, Lei and Liu (2016) and Gholaminejad and Anani Sarab (2020) developed discipline-specific academic wordlists using the new-GSL (Brezina \& Gablasova, 2015). 
is also suggested that teachers and test developers use lemma-based wordlists such as the new-GSL (Brezina \& Gablasova, 2015) and the Academic Vocabulary List (AVL) (Gardner \& Davies, 2014) for teaching and testing the core general and academic vocabulary. Language syllabus makers and curriculum designers also need to consider drawing on lemma-based wordlists such as the new-GSL and the AVL in designing the ELT syllabi or curricula.

It is required that EAP teachers and test developers be aware of the disciplinary variation at the level of academic words and use discipline-specific academic wordlists for teaching and evaluating the academic vocabulary. Syllabus makers and curriculum designers also need to use discipline-specific academic wordlists to develop separate syllabi and curricula for each discipline based on the idiosyncratic lexical characteristics of each discipline in order to meet the specific academic needs of the students of each discipline.

\section{References}

Brezina, V., \& Gablasova, B. (2015). Is there a core general vocabulary? Introducing the new general service list. Applied Linguistics, 36, 1-22.

Cabré, M. (1999). Terminology: Theory, methods, and applications. John Benjamins.

Charles, M. (2013). English for academic purposes. In B. Paltridge \& S. Starfield (Eds.), The handbook of English for specific purposes (1 ${ }^{\text {st }}$ Ed.) (pp. 137-153). John Wiley \& Sons, Inc.

Chen, Q., \& Ge, G. C. (2007). A corpus-based lexical study on frequency and distribution of Coxhead's AWL word families in medical research articles (RAs). English for Specific Purposes, 26, 502-514.

Chung, T. M., \& Nation, P. (2003). Technical vocabulary in specialized texts. Reading in a Foreign Language, 15(2), 103-116.

Chung, T., \& Nation, I. S. P. (2004). Identifying technical vocabulary. System, 32, 251-263.

Corson, D. (1997). The learning and use of academic English words. Language Learning, 47, 671-718.

Coxhead, A. (2000). A new academic word list. TESOL Quarterly, 34, 213-238.

Coxhead, A., \& Nation, I. S. P. (2001). The specialized vocabulary of English for Academic Purposes. In J. Flowerdew \& M. Peacock (Eds.), Research perspectives on English for Academic Purposes (pp. 252-267). Cambridge University Press.

Dang, T. N. Y., Coxhead, A., \& Webb, S. (2017). The academic spoken word list. Language Learning, 67(4), 959-997.

Gardner, D., \& Davies, M. (2014). A new academic vocabulary list. Applied Linguistics, 35(3), 305327.

Gholaminejad, R. \& Anani Sarab, M. R. (2020). The academic vocabulary and collocations used in language teaching and applied linguistics textbooks: a corpus-based approach. Terminology, 26(1), 82-107. https://doi.org/10.1075/term.00043.gho 
Gholaminejad, R. (2020a). Academic vocabulary in learner writing: From extraction to analysis. WORD, 66 (1), 62-64.

Gholaminejad, R. (2020b). What do Iranian undergraduate students of social vs. natural sciences say about their language needs? International Journal of Research in English Education, 5(1), 104115.

Green, C., \& Lambert, J. (2018). Advancing disciplinary literacy through English for academic purposes: Discipline-specific wordlists, collocations and word families for eight secondary subjects. Journal of English for Academic Purposes, 35, 105-115.

Hirsh, D., \& Nation, P. (1992). 'What vocabulary size is needed to read unsimplified texts for pleasure?' Reading in a Foreign Language, 8, 689-96.

Hsu, W. (2011). EFL business postgraduates' source. The Asian ESP journal, 7(4), 63-99.

Hsu, W. (2014). Measuring the vocabulary load of engineering textbooks for EFL undergraduates. English for Specific Purposes, 33, 53-64.

Hyland, K., \& Tse, P. (2007). Is there an “academic vocabulary”? TESOL Quarterly, 41(2), 235-253.

Kuehn, P. (1996). Assessment of academic literacy skills: Preparing minority and limited English proficient (LEP) students for post-secondary education. California State University (ERIC Document Reproduction Service No. ED415498).

Lam, J. (2001). A study of semi-technical vocabulary in computer science texts, with special reference to ESP teaching and lexicography (Research reports, Vol. 3). Language Centre, Hong Kong University of Science and Technology.

Lei, L., \& Liu, D. (2016). A new medical academic word list: A corpus-based study with enhanced methodology. Journal of English for Academic Purposes, 22, 42-53.

Li, Y., \& Qian, D. (2010). Profiling the academic word list (AWL) in a financial corpus. System, 38 , 402-411.

Liu, J., \& Han, L. (2015). A corpus-based environmental academic word list building and its validity test. English for Specific Purposes, 39, 1-11.

Martínez, I. A., Beck, S. C., \& Panza, C. B. (2009). Academic vocabulary in agriculture research articles: a corpus-based study. English for Specific Purposes, 28, 183-198.

Mudraya, O. (2006). Engineering English: A lexical frequency instructional model. English for Specific Purposes, 25(2), 235-256.

166 Nation, I. S. P. (1990). Teaching and Learning Vocabulary. Newbury House.

Nation, I. S. P. (2015). Chapter 33: Which words do you need? In J. R. Taylor (Ed.). Handbook of the Word (pp. 568-581). Oxford University Press.

Nation, P. (2001). Learning vocabulary in another language. Cambridge University Press.

Nation, P. (2013). Learning vocabulary in another language (2 ${ }^{\text {nd }}$ Ed.). Cambridge University Press.

Paquot, M. (2010). Academic vocabulary in learner writing: From extraction to analysis. Continuum.

Provalis (2016). Prosuite: Wordstat [computer software]. Montreal. 
Quero, B., \& Coxhead, A. (2018). Using a corpus-based approach to select medical vocabulary for an ESP course: The case for high-frequency vocabulary. In Y. Kırkgöz \& K. Dikilitaş (Eds.). Key issues in English for specific purposes in higher education (pp. 51-75). Springer, Cham.

Schmitt, N., \& Schmitt, D. (2012). A reassessment of frequency and vocabulary size in L2 vocabulary teaching. Language Teaching, 47(4), 1-20.

Schmitt, N. (2000). Vocabulary in language teaching. Cambridge University Press.

Sutarsyah, C., Nation, P., \& Kennedy, G. (1994). How useful is EAP vocabulary for ESP? A corpus-based case study. RELC journal, 25(2), 34-50.

Valipouri, L., \& Nassaji, H. (2013). A corpus-based study of academic vocabulary in chemistry research articles. Journal of English for Academic Purposes, 12(4), 248-263.

Vongpumivitch, V., Huang, J. Y., \& Chang, Y. C. (2009). Frequency analysis of the words in the Academic Word List (AWL) and non-AWL content words in applied linguistics research papers. English for Specific Purposes, 28, 33-41.

Wang, J., Liang, S., \& Ge, G. (2008). Establishment of a medical word list. English for Specific Purposes, 27, 442-458.

Ward, J. (2009). A basic engineering English word list for less proficient foundation engineering undergraduates. English for Specific Purposes, 28(3), 170-182.

West, M. (1953). A general service list of English words. Longman.

Yang, M. (2015). A nursing academic word list. English for Specific Purposes, 37, 27-38. 